\title{
Children's Roma Literary Protagonist with a Social Disadvantage in the Emotional Education
}

\author{
Bibiána Hlebová ${ }^{1}$ \\ ${ }^{1}$ Department of Special Education, Faculty of Education, University of Prešov, Slovakia \\ Correspondence: Assoc. Prof. Bibiána Hlebová, Ph.D., Department of Special Education, Faculty of Education, \\ University of Prešov, 17. Novembra 15, 08001 Prešov, Slovakia. Tel: 421-51-7470-570.
}

Received: December 14, 2016

Accepted: December 29, 2016

Online Published: February 21, 2017

doi:10.20849/ajsss.v2i1.114

URL: http://dx.doi.org/10.20849/ajsss.v2i1.114

\begin{abstract}
Author of the paper deals with the current issue which is the co-existence of Romany students (Roma minority social group) coming from the socially disadvantage backgrounds and marginalized Roma communities together with the non-Roma students from the major society in Slovakia in school inclusion settings. In this process, the author attaches significant importance for the development not only of cognitive (intellectual quotient - IQ), but also of emotional intelligence (emotional quotient $-E Q$ ) of all the students through artistic pictures of the Roma people coming from socially disadvantaged backgrounds marked by poverty a compliance with internal rules of the Roma identity (romipen) in the Slovak literature for children and youth. In this regard, author roots in the artistic delineation of emotional world of the Romany child protagonist - boy Lajko in an auto-biographical novel from Romany writer Ludovít Didi Stories blessed by the wind with the subtitle On the Romany soul, where the author displayed fates of people in very unusual way. Child literary protagonist from socially disadvantaged backgrounds perceives the social differences very sensitively in the intentions of own, minority society as well as in the co-existence of Roma and non-Roma people. Observation and empathetic experiencing of the negative emotional world of Romany child protagonist, the author used within emotional education and development of emotional intelligence of Roma and non-Roma students in the school inclusion settings in Slovakia.
\end{abstract}

Keywords: children's Romany literary protagonist, social disadvantage, emotional education, school inclusion

\section{Introduction}

More recently in Slovakia, the issue of collective emotional crisis which consists in the increasing of cognitive intelligence (intellectual quotient $-I Q$ ) and decreasing of emotional intelligence (emotional quotient $-E Q$ ) in children and youth comes to the centre of attention of psychologists and educators. There is also a well-known statement which says that we are educated but ignorant. Escalating impulsive, aggressive and violent behaviour of young people, racial and ethnic intolerance, but also loneliness and depressive mood states of children and youth are alarming. This state is also related to the current trend of social, economic and cultural globalization of the world and the alienation of man by man, which in Slovakia resulted into deepening of social differences among the major and minority (Romany) population, which is very diverse ethnically, socially, and culturally. Although some of the Roma people have integrated into the major society already, there is still a numerous group of Roma who live by the periphery of society in social exclusion (marginalised Roma communities), i.e. in economical. Political, cultural, and environmental exclusion and poverty (Ministry of Education, Slovak Republic, 2012). Social maladjustment of these Roma people is a problem that affects everyday coexistence of the adult Roma and non-Roma people, but also the Roma and non-Roma students at school in negative way. In the modern $21^{\text {st }}$ century, we should be sufficiently prepared for the coexistence of several nations, nationalities and ethnic groups. The ability to listen to others, understand them, respect them, and to be able to live with them and cooperate is known as multicultural competence. Its integral part is also the improvement of positive feelings and emotions, i.e. emotional education and development of emotional intelligence (EQ), because through the self-recognition and self-experiencing we could come to better recognition and understanding of others.

Process of societal, cultural and artistic integration of the Roma people into the pluralistic majority society takes on a new dimension particularly after the 1989 in Slovakia. Roma people, from the point of view of most of the non-Roma people, became to be seen as peculiar ethnic group, which has its own culture, language, habits, and traditions, norms of social behaviour and coexistence, and which, not only in a real world, but also in the literary 
arts, keeps archetypal characteristics of its Roma identity (romipen). In the artistic literary images, the Romany protagonists take character of specificity and otherness of another protagonists just because they are Roma, i.e. they have different origins and social status, represent different way of life, specific value hierarchy. According to P. Andruška (2000), we reflect the Roma ethnic group "in a gimped form of romanticising veil of exotica and adventure... A Roma man adorns, complicates, and dramatizes life... Romany emotionality is authentic" however, exploration and reflection of the Roma (gipsy) issue was related to the increasing need for acute addressing of the issue in wide level, the Roma issue has spilled beyond the ethnographic peculiarities and has become an issue of cultural, social, societal, and political dimension.

Romany literary folklore, Romany traditions, their reflection of the world and life philosophy are an integral part of the Romany identity (romipen) (Hlebová, 2010, 2015, 2016) kept in a community from generation to generation. The term romipen according to M. Hübschmannová (1988) has various meanings; romipen does not represent only Roma culture, tradition, mentality, but also the compliance with some unwritten laws, such as generosity, support, and the cohesion among Roma people, etc. According to M. Vágnerová (1999), Roma identity (romipen) might be identified on the basis of anthropological characters (they show distinctness of their face and livery; they act as an apparent confirmation of the total difference), but also on the basis of the ethnic signs (own language, norms, values, culture, traditional way of life), which differ the members of the minority from other social groups, especially the majority. Specificity of Roma people confirms also E. Lacková (1992): "Us, Roma people, we are particular. Inimitable. It is really necessary to understand our inner selves, our hearts. We are different from the majority not only by the colour of our skin, anthropologically, but we differ by our inherited temperament and other characteristics that make us, Roma people, real Roma. Our Roma heart cannot be re-created."

Even in the contemporary literature for children and youth in Slovakia comes to forefront the production of Roma and non-Roma authors who seek nonviolent promotion of Roma identity (romipen) into the literary arts. Romany literary text thus becomes a tool for recognition of the Roma otherness, i.e. their behaviour and acting, thinking and feelings, way of life and life philosophy. Romany literature follows the traditional Romany folklore, which is one of the most characteristic ethnical determinants and features of Roma people. When defining the term Romany literature we follow the definition of literary text from T. Žilka, where the Romany literature is " $a$ result of specific image of the reality, culture, and traditions of Roma ethnic group in a particular area; it is defined by elementary communication aspects: reality reflection, following the traditions, subjectivity representation of an author and the sustained due regard to the reader" (Žilka, 1987).

\section{Method}

On a basis of literary-historical research of Romany literature for children and youth in Slovakia within the Roma folk-tales (paramisa) from Roma authors - Dezider Banga, Ján Berky-Luborecký and Elena Lacková, we identified characteristics of Roma identity (romipen) and archetypes of Roma social group, which, form the historical point of view, represent characteristics typical for primary way of life of the Roma population ancestors living in tribes. It was found on the basis of historical-ethnographic research of Roma people from E. Davidová (2004) and research of the Romany folklore genres form M. Hübschmannová (1998) which were categorized into thematic areas (more detailed In: Hlebová, 2010, 2015, 2016):

\section{External and internal characteristics of Romany protagonists}

(anthropological characteristics, temperamental characteristics - narrative talents, bravery, slimness, sense of humour, fussiness, laziness, musical talent, singing and dancing).

\section{Images from the Romany protagonists' life}

(nomadic way of life, housing style, craft skills, different way of life, artistic talents, household economic and nutrition, clothing).

\section{Interpersonal relationships of Romany protagonists}

(Romany family, ancestral bond, internal rules, male status, naming the persons from a family, joint sittings, sense of cohesion and cooperation, mutual solidarity, respect to elders, aggressive behaviour).

\section{Spiritual world of Romany protagonists}

(folk religion, faith in God, belief in supernatural powers, superstitions, magic and witchcraft, souls of the dead, folk medicine, life philosophy).

In the intentions of outlined thematic areas of Roma identity (romipen) we will deal with issue of using the emotional education and improvement of emotional intelligence (EQ) of students through understanding and 
experiencing the emotional world of Romany child protagonist (boy Lajko) in autobiographical novel from Roma writer Ludovít Didi Stories blessed by the wind with the subtitle On the Romany soul (2004) in terms of school inclusion of Roma students.

Romany students coming from socially disadvantaged backgrounds (also from marginalised Roma communities) in Slovakia, due to the social, language, and cultural barriers, are the students with special educational needs, who require special treatment in the educational process, and therefore they are educated in special schools or in special classrooms, or they are individually integrated in the mainstream schools. Contemporary educational programs for children and youth with special educational needs follow the long-term Conception of the education of children with disabilities (Ministry of Education, Slovak Republic, 2010) focused on the acceptance of changes in the social system and implementation of current scientific development knowledge form psychology, medicine, engineering, and other scientific fields into the education area. Their main task became the requirement for social integration and inclusion of children and youth with disabilities and social disadvantage, creating optimal conditions for their education with emphasize to their individual interests, abilities, and potentialities (Constitution of the Slovak Republic, 1992). Within the creative-humanistic conception of education, the importance is given on the own potential of students (not only the cognitive process of gaining knowledge), on the development of their individual skills and potentialities so that they could gain knowledge, skills and abilities necessary for further professional training, in order to create the right attitudes and positive relation towards others, towards himself and the environment, i.e. on their maximal possible development in terms of cognitive, sensual, emotional, motivational, psychological, and physical abilities, and the compensation of their insufficiencies with the objective to increase their school success and prepare them for practical life in the adulthood in society. Education of the Roma students in terms of school integration and inclusion at elementary schools in Slovakia constantly alludes to shortcomings in the management of schools, professional training of the teachers, and promoting specific material tools for those students, as well as the cooperation between school and family, despite its legislative basis in the school documents (Education Act, Ministry of Education, Slovak Republic, 2008). Within the creative-humanistic education focused on interests and needs of each student, a teacher can incentively and effectively implement emotional education with an intention to avoid negative behaviours of the students, particularly bullying, discrimination, intolerance, as well as various signs of racism against the students, who differ from majority group. And in terms of International Bill of Human rights and Convention on the Rights of the Child $(1989 ; 1991)$ teacher can also attempt to eliminate the problems related to segregation of Roma population in his classroom. Under the supervision of such teacher, a classroom heads towards mutual support, respect, tolerance, and not ridicule and humiliation. However, a teacher should know perfectly not only the personalities of his students, but also their mutual relationships, particularly between the minority and majority groups. Also the Romany student must have an opportunity to "fight" with a problem and learn to solve it. An experience of each activity which is supervised by a teacher, is aimed to enrich a personality of each student, contribute to contribute to improvement of relationships in students' collectives, and to axiology and auto-regulation in all of the students. It all takes place in a convergence with teaching topic its mastery and building a positive attitude towards the curricula. "Cognitive processes converge with emotional and motivational processes, which lead to self-regulationmanagement of the processes related to thinking and feeling considering tasks and aims, and thus lead to the behaviour of a man," states M. Zelina (2008).

Development of feelings and emotions through systematic emotional education has a significant importance for a child as in family as well as in a school. Definition of a term feeling, understood as "experiencing subjective relationship of a man towards objects and phenomena of external world, as well as towards himself," (In: Durič \& Štefanovič, 1973) offers a basis for practice. Emotional experience of a student can cause various emotional states. It can be affects (short-term and stormy ongoing emotional gusts of extraordinary intensity that can occur as burst of laughter, anger, cry, etc.); moods (long-term emotional relations of lower intensity, which may occur as a mood happy, sad, anxious, grumpy, etc.); passions (long-term emotional relations of strong intensity). Some manifestations of feelings might be observed externally also, e.g. in the facial expressions, gesticulation and mimics, in changes of breathing and behaviours of a child. Emotions, according to D. Märtinová (1998), help us to "respond immediately in unexpected situations, decide quickly, and communicate with others without words." According to I. Stuchlíková (2007) "emotions are a part of wider group of so called affective phenomena, where belong also moods or emotional episodes (including emotional swings among the protagonists of a certain stage)." Beginnings of the feelings and emotions formation in every man belong to a period of his childhood and it is related to its natural curiosity and a desire to understand new things and contact adults, who surround him and whose behaviours a child observe and simulate very often. We agree with an opinion of B. Kosová (2000) who states that "the better a child perceives stimuli form the emotional site, the more he wants to know 
and to gain an insight into the heart of a matter." Thus, the feelings and emotions are one of the most important stimuli in a child's personality development, and they are sort of a barometer of his acting and behaviours. The younger a child is, the more readable his emotions are (Kožárová \& Podhájecká, 2016; Kožárová, 2016). With an entrance of a child into elementary school starts his new personality development relatively. Child entrances a new role of schoolboy, new collective of peers with an adequate level of social-emotional competencies (Dubayová, 2016). Adequately socially matured child should be able to communicate, cooperate, and differentiate the roles of a student, classmate, and a teacher seemly. According to Z. Kolláriková (2001), in the emotional manifestations of a school-age student in comparison to pre-school-aged child, the emotional lability, impulsivity and infantile egocentrism retreats; a student acquires ability to regulate his behaviours according to norms and he wants to make his teacher or/and parents happy.

With an issue of emotional intelligence dealt various Slovak authors, e.g. J. Dargová (2002), E. Gajdošová (1998, 2002), G. Herényiová (2002), Z. Kolláriková (2001), B. Pupala (2001, 2004); as well as the foreign authors, e.g. C. Rogers (1983, 1995), J. P. Rushton (1988, 1997), D. Goleman (1997, 2000), L. E. Shapiro (2004), I. Stuchlíková $(2002,2005)$. Within the current alternative programs of the emotional and personal development of a student at school, which consider him as a subject of education and emphasize communicative approach and partner relationship between teacher and student, we have been inspired by the D. Goleman's emotional intelligence conception (1997) elaborated for educational practice, which is consisted of: 1. Skills related to own personality - self-awareness, emotional self-awareness, real self-assessment, self-confidence, self-control, reliability, conscientiousness, adaptability, innovation ability, motivation towards higher objectives, ambition, loyalty, initiative, optimism. 2. Competencies within interpersonal relationships - empathy, understanding, ability to stimulate personal development of others, skills in social intercourse, flexibility, skills to influence others, communicative skills, leadership skills, ability to lead a group, willingness to comply with changes, ability to solve conflicts, ability to crate links, ability to cooperate, and the team work abilities. The term emotional intelligence was firstly used by psychologists Peter Salovey from Harvard University and John Mayer from New Hampshire University (1990) and defined it as "a part of social intelligence, which includes an ability to follow own and others feelings and emotions, to differentiate them, and to use these information in own thinking and behaviours." Simultaneously, the authors defined important emotional characteristics of a personality: empathy, expressing and understanding emotions, moods regulation, autonomy, adaptability, popularity, ability to solve interpersonal problems, endurance, friendliness, kindness, and respect. According to the mentioned authors, emotional intelligence (EQ) does not exist in the opposition with cognitive intelligence (IQ), but on the contrary, both of them mutually complement each other, while EQ is in comparison with IQ genetically much less congested, which means far too much opportunities and possibilities for acquiring the success of a students in the educational process.

\section{Results}

In this regard, in the educational process we might be inspired by mentioned theory of emotional intelligence development in students, through understanding and experiencing the emotional world of child Romany protagonist with a social disadvantage from autobiographical novel from L. Didi Stories blessed by the wind with subtitle On the Romany soul (2004). In unusual way (memories from own childhood spent in a wide Roma family), the author depicted fates of people from authentic Roma environment at close quarters to the major society. The main protagonist of mentioned book is Roma boy Lajko, who in his memories makes extraordinary emotional experienced events from his childhood present, and later from his adulthood as well. Child Romany protagonist coming from socially disadvantaged backgrounds is significantly stigmatized by negative feelings and emotions, which he experiences in poor Roma family with a strict compliance with internal Romany rules. Since early childhood, the boy very sensitively observes social differences in intentions of own, minority society, as well as in the coexistence of Roma and non-Roma people, to whom he builds his own critical attitude until his adulthood. Since the Romany time does not heal, every past evil comes to life in his emotions with greater intensity.

\section{Emotional world of Romany children's literary protagonist with a social disadvantage}

Following part of the paper will deal with the identification of negative feelings and emotions of Romany children's literary protagonist with a social disadvantage - a boy Lajko (derogation, injustice, humiliation, disappointment, sadness, anger, fear, but also compassion and empathy for others suffering), which we recorded since his childhood until his adulthood in the novel from L. Didi (2004) Stories blessed by the wind. On the Romany soul (2004) and which we present in terms of preserving archetypal features of Romany identity (romipen) (more detailed In: Hlebová, 2010, 2015, 2016): 


\section{External and internal characteristics of Romany protagonists}

(anthropological characteristics, temperamental characteristics - narrative talents, bravery, slimness, sense of humour, fussiness, laziness, musical talent, singing and dancing):

- Lajko experienced the greatest derogation at St. Nicolas day - in tatty and in a large winter blizzard he rushed to the community house, where there was a lot of children, fathers, and mothers. Getting through the stage, he wanted to get quickly, where "sits St. Nicolas, who does not forget anyone. Behind him stay angels and smirking Old Nick. ... And I am staying, waiting and listening, as St. Nicolas raises his hands and calls the names of everyone. He gazes at me also, as he would know that I will be awarded also. Because St. Nicolas awards children for their obedience and kindness. Also have I been obedient, therefore I deserve a gift" (Didi, 2004). Lajko eagerly awaited when St. Nicolas calls his name, when he will be awarded. He was a bit confused why there is not his mother, grand-mother, or anyone from the family. Lajko sadly looked at the last gift, but even that one was not for him. He was sad and disappointed and he thought: "Probably St. Nicolas forgot me" (Didi, 2004). He came back home very sad and he complained to his grand-mother: "St. Nicolas was awarding children with gifts, but I did not get any. ... I was also kind and obedient whole year, I also deserved one" (Didi, 2004). However, Lajko gets very cold answer from his grand-mother that St. Nicolas is not handing out gifts in real life. And he also got a slur that he is "donkey" and wallop under his ribs - this was his real "St. Nicolas present".

- Lajko's disappointment in own family, where he realized that in his surrounding are also cagey and false Roma people. There were two brothers with nicknames Jager and Frak, who gained the confidence of grand-mother and grand-father by various frauds and lies... Grand-father was very angry and said that "honest person always suffers for vagabonds" (Didi, 2004).

- Sensitive perception and observation of the Romany people life in his surrounding and understanding of life principles, which Roma people have always followed, brought to Lajko new knowledge. He did not like that "most of the time Roma men lounge, wallow from site to site, while the women and children are begging outside. ... Roma man will never work, after all, he has not worked since the world existed" (Didi, 2004). Moreover, he considered as incorrect the way how other Roma people ensured their livelihoods. Most often it was robbery, but also assaults, battles, various kinds of violence, threats and even murder for which they were often punished and imprisoned.

\section{Images from the Romany protagonists' life}

(nomadic way of life, housing style, craft skills, different way of life, artistic talents, household economic and nutrition, clothing):

- The greatest derogation and injustice that Lajko met in his life was poverty. He lived in a tiny tatty house, where he often felt hunger, thirst, misery, and lack of food and clothes.

- Also, derogation and injustice for Lajko was that since his early childhood ha had to go to neighbours to work in order to ensure some livelihood (for the worked he was paid with potatoes, jam, cottage cheese, sometimes poultry, cabbage, bread, or money), and what he earned he just had to give to his family: "Often I brought home a lot of money... without words I emptied my pockets, put money on a table and sick with cold crawled into corner, to my miserable bed" (Didi, 2004).

- Another derogation which Lajko experienced was hard physical labour, which he had to do hungry straight after coming home from school at the "Red necks" (non-Roma).

- The greatest humiliation Lajko felt when he met a trader and he himself had to drag a cart with goods just for one loaf of fresh bread. When he came back home and took off his jacket and shirt, he had red stripes on his back from the rough tether. And then he felt derogation from his relatives, when his grand-father and two of his uncles did not help him, "it would be enough if they would take a tether, put together, tie up all load and put on a back..." (Didi, 2004).

- Another derogation that Lajko experienced was that there was no one who would help him, indeed his classmates made fun of him what hurt a lot.

- Great derogation and shame for Lajko was also a fact that he had to beg, when his Roma family starved. In such situation, all family members were arguing. Usually, grand-father solved the issue, took Lajko and together went for begging - grand-father played violin and Lajko had to sing. And then Lajko often witnessed mockery from his classmates, but also miserliness of rich "red necks" (non-Roma). 
- Lajko perceived sensitively how his Roma family manages money and foods unwisely. After several years Lajko understood that "a Roma man waits with eager longing some money, and when he had it, he can spent them overwhelmingly fast. But there is some logic in it: after long time of waiting you will lose a track, patience, you are spending and again, you are on the bottom. And so it was in our family as well, and so it is in many Roma families still” (Didi, 2004).

- Lajko also sensitively perceived incorrect life philosophy and life style of the Roma people, especially their unwise household economics, lack of interest in work, irresponsibility for family, and relying on the hard work of women. Everyday phenomena was begging, thefts, lies, frauds, slumps, fights, argues, threats, but also murders.

- And finally, derogation for Lajko was also a fact that he could not continue in his studies, even he was very smart in learning and sports as well.

\section{Interpersonal relationships of Romany protagonists}

(Romany family, ancestral bond, internal rules, male status, naming the persons from a family, joint sittings, sense of cohesion and cooperation, mutual solidarity, respect to elders, aggressive behaviours):

- Injustice for Lajko was also that even he grew up in a wide Roma family together with his mother, aunt, two uncles, grand-mother and grand-father, but without father, so he was "illegitimate".

- Another injustice was that since his early childhood he never felt sacrificial love of the parents, only his grand-mother and grand-father raised him, what he was comparing with his peers.

- Injustice for Lajko were also situations, when in his Roma family he was often pushed behind and unrecognized. Sometimes, when the family sat together by a table full of foods, usually he got the smallest piece of meat and the smallest portion. Then he had to settle for grand-mother's response that he is the youngest, and therefore he had the least on his plate. The fact that even he is earning and contributing to the family livelihood the most, he always got the last, hurt him a lot.

- Injustice was experienced again, when the family decided on the money that he earned. Whether it will be used for bread or cigarettes, "cigarettes won, stomachs were empty and bleached gain” (Didi, 2004).

- Lajko felt compassion and empathy towards other people (both Roma and non-Roma), who suffered their misfortune, for example very sensitively he perceived a narration about unhappy man - musician Pišta, whose girlfriend left him because of his hump. The musician was sinking his grief in a pub with other Roma men, who "were on scrounge", did not work anywhere and were only waiting for any guest to drink for his money, which makes Lajko very angry. Also Lajko eagerly listened stories about two village wanderers - mad Pišta from a village called Malichov who earned just with begging and whom other Roma men defrauded many times, also one of his uncles did it. The other wanderer was handsome Roma with a nickname Štern̆a. He could read and write, moreover he could speak Polish, Hungarian, and Romanian. During the War, he was decorated and promoted to lieutenant. He liked to brag about, until one day he paid for mischief of another Roma, who made him to marry his daughter by a fraud.

\section{Spiritual world of Romany protagonists}

(folk religion, faith in God, belief in supernatural powers, superstitions, magic and witchcraft, souls of the dead, folk medicine, life philosophy):

- $\quad$ From the story-telling of adult Roma in the family, Lajko learns about things, which gave him a fright, e.g. about mulans (spirits of dead) or about tragic events that mate Roma and non-Roma people.

- Lajko's first emotional contact with death of loved one was related to the illness of his beloved grand-father Ondráš. He had a cancer. "This night I had a weird dream. Our big kitchen was full of strange people. By the door of the bedroom stood a tall Roma man with the same moustache as my grand-father used to wear. Next to him was grand-father's mother, and many other Roma people, men and women, all of them were Roma, in their faces there was a similarity, but the one by the door was the most similar to my grand-father. There was his father, grand-father, grand-grand-father, the closes family... I am sure that they came because of him, his relatives from the same root, and they were waiting for him so to take care for him in the first moments after his death..." (Didi, 2004)

- Lajko bucked the evil, never acted wrong, nor hurt anyone, did not revenged evil by evil, although he mediated about it and evaluated. Life story of Lajko in the novel ends in a circle of his own family in his adulthood next to his beloved wife and son. People around considered him to be a decent man, as he worked and responsibly took care for his family. The evil that he experienced with his family and mother he forgot quickly. 
He built up his own home, graduated university, and lived a proper life with his wife. Political changes in a society after 1968 and signing the Chart 77 brought to Lajko's life, i.e. author life, negative emotions again, which were related to his persecution, hearing, free expression prohibition, hard work, and humiliation.

- To live and survive are the last words of the novel, which express symbolically a life philosophy of Roma people and which Lajko understood in his adulthood and which brought to his life so much derogation and disappointment in his childhood. By faith in God and life philosophy "to live and survive, here and now", Lajko have always managed to "bounce back from the bottom" and to overcome all barriers.

We believe that Roma author Ludovít Didi in his novel Stories blessed by the wind managed to disrupt relatively well-known idea that "the evil comes from a human temperament and it occurs everywhere."(Benčič, 2007). Although the novel Stories blessed by the wind is about "the cry of gypsies, and mainly about gypsy soul" (Sliacky, 2005), but the soul is in a case of L'. Didi extraordinary emotive, sensitive, and oriented on sake, what finally is a win of conscious and freedom of thinking.

While knowing and understanding the emotional world of children's Romany literary protagonist (boy Lajko), but also the whole Roma minority group, which is still preserving some archetypal characteristics in their way of life, we might lead the students to thinking and understanding of the otherness in Roma people. Our objective is to strengthen in non-Roma students the emphatic experiencing of negative feelings and emotions of Roma boy Lajko and to understand it, and moreover, to support positive feelings and emotions and through them eliminate prejudice and intolerant behaviours towards Roma students. On the other hand, our intention is to strengthen in Roma students their self-confidence, self-identification with own ethnic group, and prosocial behaviours towards non-Roma classmates. In school collectives of Roma and non-Roma students in inclusive settings within emotional education is important to improve in all students activities focused on mutual understanding and acceptance. As effective methods might be considered those, which are based on the cooperation of students (e.g. group learning, project education), as well as an implementation of therapeutic-formative approaches form drama-therapy and bible-therapy (Hlebová, 2016). The target scope of mentioned approaches heads towards self-awareness and respect of others, socialization and stimulation of communication with environment, change of attitudes and values, to overcoming of depressive moods, positive emotional stimulation, tension reduction, empathy development, exercising social behaviours forms and solving critical issues of individuals, increasing of social relations, prosocial behaviours, improving psychological balance, development of divergent thinking, and ability to solve the problems (Žolnová \& Semanová, 2016), etc., i.e. towards comprehensive personality development of each student without any difference through an experience, which is implemented in the meaning of exploring, revealing, and understanding,

Our reflections on the emotional education of students are confirmed also by J. Skalková (1995) in her reflection on educational innovations in contemporary inclusive school, which should root from the social context and touch "new structures of a school, their content, methods, or focus of values change," while this should not be "a random measure, just ideas, or goal-oriented tendencies." In this meaning, the author prefers current require of cultural, aesthetic, and emotional development of a student, within open education in everyday practice of alternative knowledge from developmental psychology and cognitive psychology from authors J. Piaget, L. S. Vygotsky, etc., who bring new ideas about thinking, learning, and acquiring knowledge. We agree with an opinion of J. Skalková (1995) that in an open education the focus is given on fundamental change of educational attitude in terms of internal (towards a student at school) and external opening up (towards external, extra-curricular world), which also includes an establishment of qualitatively new relationship of teacher and students. Open education principle changes a position of teacher in educational process to manager, who accepts students, helps them in their personality development, builds relationships of mutual respect, and organizes their work in order to allow each student to experience more the feelings of success and failure, appropriately creates situations, in which he teaches his students to take responsibility for own acting and behaviours.

Emotional world of children's Romany protagonist with a social disadvantage within emotional education of students according to recommended thematic areas from G. Herényiová (2002) we focused on creative emotional communication with students:

\section{- Understanding own emotions}

Objectives: Self-awareness, student is able to recognize his feelings and emotions at the moment of its occurrence.

Topics for creative emotional communication with students:

1. Express (verbally, non-verbally) your feelings after reading literary extract. 
2. Tell us about the feelings that you expressed - were they comfortable, awkward, cheerful, sad ...

3. Tell us about any similar situation, which made you feel awkward, sad, hurt.

4. What hurt you the most?

5. Why did it hurt you?

6. Have you experienced more of such situations?

7. When did you feel the greatest derogation or injustice?

8. Why did you why did you see it as injustice?

9. Can you explain the meaning of word injustice/derogation?

10. Are you able to recognize, when someone experiences injustice?

\section{- Emotions management}

Objectives: Student is able to calm down his excitement, anxiety, and irritability.

Topics for creative emotional communication with students:

1. Tell us how you coped with an injustice that really hurt you.

2. Explain why you felt that way.

3. What did you do as first then?

4. Who helped you the most in this situation?

5. Tell us how that person (parent, brother, sister, friend, teacher) helped you.

6. Did that person offered you his/her help spontaneously?

7. Did you ask anyone to help you?

8. Did you have to manage that injustice on your own?

9. Was there anyone to help you?

10. Who you would like to ask for help, if you would meet any injustice again?

\section{- Ability to motivate yourself}

Objectives: Student is able to use his own emotion as an intrinsic motivation.

Topics for creative emotional communication with students:

1. Tell us how you feel when we are talking about injustice.

2. Is it comfortable or awkward for you to talk about the topic?

3. If is it comfortable, tell us why?

4. If is it awkward, tell us why?

5. What kind of new experiences did you get today?

6. Did you learn anything new today?

7. How could you implement this knowledge for yourself?

8. Based on the mentioned situation, how would you manage the injustice that has occurred?

9. Why would you solved it this way?

10. Why did you master particularly this solution of an awkward situation?

\section{- Sensitivity to the emotions of other people}

Objectives: Student learns to be empathetic to others

Topics for creative emotional communication with students:

1. Tell us what you liked the most/least about Lajko's behaviours. Explain why.

2. Imagine you are Lajko now. How do you feel?

3. Tell us what would suffer you the most if you were Lajko and why.

4. Try to give an advice to Lajko, how should he act in a particular situation.

5. Why should he act in a way you suggested? Give him more alternatives to choose. 


\section{Think about all of the injustice that Lajko had to overcome. List them.}

7. Tell us what of all injustice situations do you consider the most hurting and why?

8. If you would have to live like Lajko, how would you feel? Explain your feelings.

9. Would you like to have a friend like Lajko? If so, argument why. If don't, argument why.

10. Tell us about any of your friends. Would you help him, if he would face any awkward situation?

\section{- Art of interpersonal relations}

Objectives: Student is able to empathize with emotions of others and thus adapt his behaviours

Topics for creative emotional communication with students:

1. Imagine the situation that a new classmate like Lajko is coming to your class.

2. How would welcome him?

3. What would you noticed at him at first?

4. Would the thing you have noticed at him as first be the crucial and decisive?

5. Would you observe him at learning, behaving toward other classmates or teachers?

6. Would you like to be similar to him in any way? In which way?

7. Would you like to be a friend with him? If so, argument why. If don't, argument why.

8. If you would like to help him with anything, how would you do that?

9. If anyone would hurt him, what would you do?

10. Would you be able to be fair to him? Why so? Why not?

\section{Discussion}

According to psychiatrist Michael Norden from Seattle (In: Shapiro, 2004), in a process of emotional education of a student, the most interesting fact is that during the process, we can influent changes of biochemical matters in a brain. One of those is neural mediator - serotonin, which creates emotional reactions by transporting emotional messages from brain into different parts of a human body. Therefore the importance of serotonin for emotional life of a child is invaluable, because it influences many physical factors (body temperature, blood pressure, digestion, sleeping, etc.) and it can help children to cope with various kinds of stress by preventing brain overload with incoming information. Increased level of serotonin is associated to elimination of aggression and impulsivity, which we can easily reach, for example with smiling. For a teacher it indicates that he should be smiling and make his students smiling not only within the emotional education, and thus induce joyful atmosphere for students. We agree with an opinion of L. E. Shapiro (2004) that if we want to change students' behaviours, we have to change the way of his brain development. Development of emotional skills of students, positive emotions and emotional thinking while solving problems with adequate relaxing and psycho-therapeutic methods, games, and events we might simulate and regulate their behaviours and functioning in interpersonal relations, not only in childhood, but in the adulthood as well.

Teacher is supposed to direct educational process in order to inhibit pleasant emotional states in his students and to have optimal working atmosphere in a classroom. Here a teacher can fully use positive emotional situations in students for the negative feelings and emotions removal. According to B. Kosová (2000), it is a teacher who is a creator of emotional security, emotional warmth, to which the students can contribute if they have fulfilled following conditions - student can satisfy his basic needs, student can develop his self-esteem, student have a certain extent of free decision, there is an equality in chances and justice in a classroom, and there is cheerful and humorous atmosphere in a classroom. Reinforcement of positive emotions and emotional intelligence development of students in primary education is the most appropriate prevention of emotional problems, and a premise of gaining good results in educational process. Only a teacher, who is aware of emotional needs and problems of his students is able to influence understanding of different attitudes, opinions, relations, and confrontation of own and others' emotions through emotional (experiential) learning in a desired way. We believe that using literary arts in the emotional education of all students could be the right way, which is related to understanding and perception of minority Roma culture in majority school collective, which includes as Roma as well as non-Roma students. The focus is given on sensual development, perception of own feelings, development of phantasy and creativity in students, and their emotional experiencing through artistic text from Roma literature, and with specifically focused tasks that support emotional intelligence of students. Therefore in school practice, the conception of creative-humanistic education is highlighted by current requirement of mutual understanding and knowing, respecting people from different nations, nationalities, ethnic groups, i.e. 
implementation of emotional education conception into educational process focused on the development of emotional intelligence (EQ) in students in primary education already.

In the paper we attempted to point out possibilities of overcoming the ongoing issues in coexistence of Roma and non-Roma students, which are accompanied with prejudice, intolerance, aggression, and racism on both sites, while the focus is given on harmonic development of cognitive (multicultural) and non-cognitive (emotional) competencies of all students through emotional education and emotional intelligence development in all students while working with Roma literary text and children's Romany literary protagonist with a social disadvantage, so we might create appropriate conditions for inclusive education of students coming from the Roma minority group in Slovakia.

\section{Acknowledgements}

Study is part of a research project APVV-15-0071 A man with handicap in literature for children and youth $(2016-2020)$

\section{References}

Andruška, P. (2000). Literárna tvorba národnostných menšín. Nitra: FF UKF.

Benčič, S. (2007). Pôvod psychických príčin pre konanie zla. In: Zlo v kontexte súčasných socio-kultúrnych premien. Prešov: PF PU, 2007, pp. 24-28.

Bruner, J.S. (1965). Vyučovaci proces. Praha: SPN.

Convention on the Rights of the Child. (1990). New York, Valné zhromaždenie OSN, prijaté 20. novembra 1989 s platnost’ou od 2. septembra 1990, oznámenie č. 104/1991 Zb.

Dargová, J. (2002). Emocionálna inteligencia a tvorivá výučba. Prešov: Privatpress.

Davidová, E. (2004). Romano drom. Cesty Romů 1945 - 1990. Olomouc: UP v Olomouci.

Didi, L'. (2004). Príbehy svätené vetrom. O cigánskej duši. Bratislava: Vydavatel'stvo Slovart.

Dubayová, T. (2016). Patopsychológia detí so psychosociálnym narušením pre pedagógov. Prešov: Vydavatel'stvo Prešovskej univerzity.

Ďurič, L., \& Štefanovič, J. a kol. (1973). Psychológia pre učitelov. Bratislava: SPN.

Gajdošová, E. (1998). Školský psychológ a jeho vstup do humanizácie našich škôl. Bratislava: Príroda.

Gajdošová, E., \& Herényiová, G. (2002). Škola rozvíjania emocionálnej inteligencie žiakov. Bratislava: Vydavatel'stvo Príroda.

Goleman, D. (1997). Emoční inteligence. Praha: Columbus.

Goleman, D. (2000). Práce s emoční inteligence. Praha: Columbus.

Hlebová, B. (2010). Rómska identita (romipen) v rómskych rozprávkach (paramisa). Prešov: Pedagogická fakulta Prešovskej univerzity v Prešove.

Hlebová, B. (2011). Slovník autorov rómskej literatúry pre deti a mládež. Prešov: Prešovská univerzita v Prešove, Pedagogická fakulta.

Hlebová, B. (2015). Romany folk-tale (paramisi) in the inclusive education of the students from Roma ethnic group. Prostějov: Computer Media.

Hlebová, B. (2016). Otherness of Roma in Inclusive Education of Roma Pupils in Slovakia. In: World Academy of Science, Engineering and Technology, International Science Index 112, International Journal of Social, Behavioral, Educational, Economic, Business and Industrial Engineering,10(4), 2393-2398

Hlebová, B. a kol. (2016). Vybrané kapitoly zo špeciálnej didaktiky predmetov (pre učitel’ov žiakov s mentálnym postihnutím). Prešov: Vydavatel'stvo Prešovskej univerzity

Hübschmannová, M. (1988). Slovesná tvorba slovenských Romů. Přehled jednotlivých žánrů. In: Slovenský národopis, 36(1), 80-91.

Kolláriková, Z., \& Pupala, B. (2001). Predškolská a elementárna pedagogika. Praha: Portál.

Koncepcia výchovy a vzdelávania detí so zdravotným postihnutím bola schválená na operatívnej porade MŠ SR dňa 18. 12. 2000 v rámci plnenia bodu B.1 uznesenia vlády Slovenskej republiky číslo 799/1997 Výhl'adové obdobie plnenia jej opatrení do roku 2015. Retrieved from http://www.statpedu.sk/files/documents/aktuality/strategie_koncepcie.pdf

Kosová, B. (2000). Rozvoj osobnosti žiaka (so zameraním na 1. stupeň základnej školy). Prešov: Rokus. 
Kožárová, J. (2016a). Differences in the perception of behavior problems in the pre-school children among the teachers and parents. World Academy of Science, Engineering and Technology, International Science Index 112, International Journal of Social, Behavioral, Educational, Economic, Business and Industrial Engineering, 10(4), 1090-1093.

Kožárová, J. et al. (2016b). Education of students with special educational needs in inclusive settings. Prešov: Vydavatel'stvo Prešovskej univerzity v Prešove.

Kožárová, J., \& Podhájecká, M. (2015). Deti s problémovým správaním v predprimárnej inkluzívnej edukácii. Prešov: Vydavatel'stvo Prešovskej univerzity v Prešove.

Lacková, E. (1992). Rómčina je jazyk, ktorým sa dá všetko vyjadrit'. PLUTKO, P., VARGOVÁ, B., ZEMAN, V.: Rómska tematika v literárnej a umeleckej reflexii. Bratislava: Vydavatel'stvo Mikromex.

Märtinová, D., \& Boecková, K. (1998). Emocionálna inteligencia - city na vzostupe. Bratislava: Slovenský spisovatel'

Podhájecká, M., \& Kožárová, J. (2016). Komplexný prístup $k$ detom s problémovým správaním. Prešov: Vydavatel'stvo Prešovskej univerzity.

Pupala, B. (2004). Výchova ako kultúrna asimilácia. In: DARÁK, M.: Aktuálne trendy v teórii výchovy. Zborník príspevkov z medzinárodného vedecko-teoretického seminára (Prešov 2. - 3. 10. 2003), II. čast'. Prešov: Prešovská univerzita $v$ Prešove, Fakulta humanitných a prírodných vied.

Rogers, C. (1983). Freedom to Learn for the 80's. Ohio: Charles E. Merrill Publ. Comp. Columbus.

Rogers, C. (1995). Ako byt' sám sebou. Bratislava: IRIS.

Rushton, J.P. (1988). Race differences in behavior: A review and evolutionary analysis. Personality and Individual Differences, 10(1), 1009-1024.

Rushton, J.P. (1997). Race, Evolution and Behavior. A Life History Pespective. New Brunswick: Transaction Publishers.

Shapiro, L.E. (2004). Emoční inteligence dítěte a její rozvoj. Praha: Portál.

Skalková, J. (1995). Za novou kvalitu vyučování (Inovace v soudobé pedagogické teorii a praxi). Brno: Paido, edice pedagogické literatury.

Sliacky, O. (2005). Príbehy svätené vetrom alebo O cigánskej duši. BIBIANA, revue o umení pre deti a mládež, $12(4), 44-45$.

Stratégia Slovenskej republiky pre integráciu Rómov do roku 2020. Bratislava: Úrad vlády Slovenskej republiky z dňa 11. januára 2012. Retrieved from www.minv.sk/?romske-komunity-uvod\&subor $=160449$

Stuchlíková, I. (2002). Základy psychológie emócií. Praha: Portál.

Stuchlíková, I. (2005). Zvládani emočnich problému školáka. Praha: Portál.

Universal Declaration of Human Rights. (1948).

Vágnerová, M. (1999). Psychopatologie pro pomáhajici profese. Variabilita a patologie lidské psychiky. Praha: Portál.

Zákon č. 245/2008 Z. z. o výchove a vzdelávaní (školský zákon) a o zmene a doplnení niektorých zákonov v znení neskorších predpisov. Štátny vzdelávací program pre primárne vzdelávanie -1 . stupeň základnej školy. Bratislava: Štátny pedagogický ústav.

Zelina, M. (2008). Inovácie v školstve - základ reformy. NOTES, 9(1), 4.

Zelina, M. et al. (2000). Koncepcia rozvoja výchovy a vzdelávania. Národný program výchovy a vzdelávania $v$ Slovenskej republike. Bratislava: MŠ SR.

Žilka, T. (1987). Poetický slovník. Bratislava: Tatran.

Žolnová, J., \& Semanová, A. (2016). Edukácia žiaka so psychosociálnym narušením na základnej škole. Prešov: Vydavatel'stvo Prešovskej univerzity.

\section{Copyrights}

Copyright for this article is retained by the author(s), with first publication rights granted to the journal.

This is an open-access article distributed under the terms and conditions of the Creative Commons Attribution license (http://creativecommons.org/licenses/by/4.0/). 